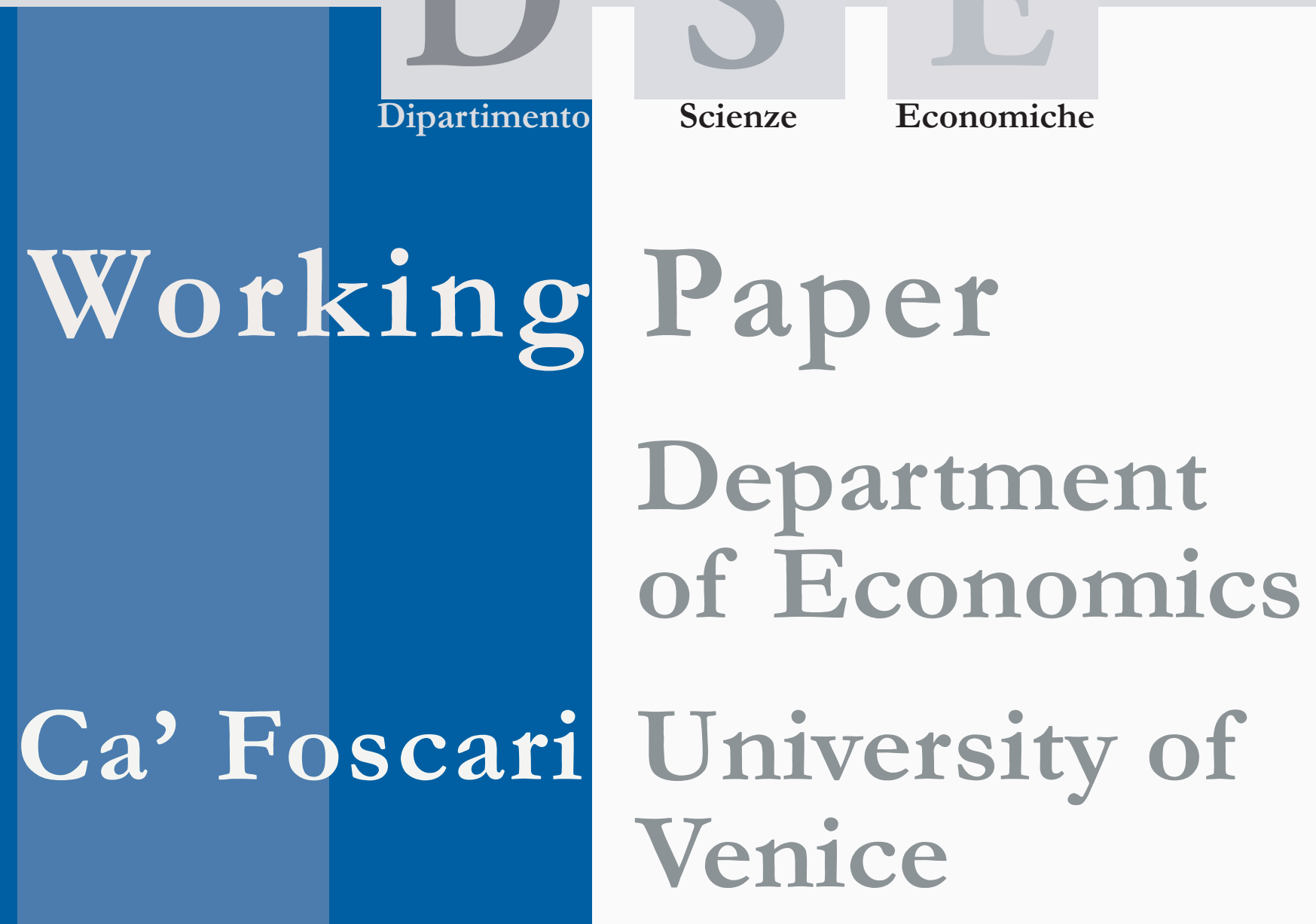

Alberto Giacomin

Maria Cristina Marcuzzo

Money and Markets: Introduction 


\title{
Money and Markets: Introduction
}

\author{
Alberto Giacomin \\ University of Venice Ca' Foscari \\ Maria Cristina Marcuzzo \\ University of Rome La Sapienza
}

First Draft: December 2005

\begin{abstract}
In the history of economic thought the relationship between money and market has been interpreted from two contrasting points of view. On the one hand, money is seen as an instrument created by individuals to overcome the difficulties involved in barter, its basic function being as a medium of exchange, while the other view has it that money developed before the market and that its principal function is that of a standard of value.

Evidently, therefore, in the former case the unit of account function is seen to have emerged from a practice (exchange of goods and services) based on the advantages to be had for individuals seeking to maximise their utility, while in the latter case money emerges as a rule adopted by members of the community (the political authorities promoting it and ensuring it be respected) which pre-dates the market.

As in the case of money, also for the market two approaches have come into confrontation in the course of the history of economic thought. With the first the market is seen as a column bearing the economies characterised by private property and freedom of enterprise. It represents the means by which members of society democratically come to decisions about the use of resources and distribution of income. In the second approach, on the other hand, the market is seen as the means by which decisions on the use of resources and distribution of income, once taken by the groups enjoying economic command, are passed on to the other members of society to be implemented. In the first case the market lies at the heart of the system and serves to prevent the enjoyment of privileges and position rents by some members of society excluding others, while in the second it merely plays a supporting role for the existing patterns of power.
\end{abstract}

\section{Keywords}

Money, markets, alternative theories

\section{JEL Codes}

B 11

\author{
Address for correspondence: \\ Alberto Giacomin \\ Department of Economics \\ Ca’ Foscari University of Venice \\ Cannaregio 873, Fondamenta S.Giobbe \\ 30121 Venezia - Italy \\ Phone: (++39) 0412349156 \\ Fax: (++39) 0412349176 \\ e-mail: albertg@unive.it
}

This Working Paper is published under the auspices of the Department of Economics of the Ca' Foscari University of Venice. Opinions expressed herein are those of the authors and not those of the Department. The Working Paper series is designed to divulge preliminary or incomplete work, circulated to favour discussion and comments. Citation of this paper should consider its provisional character.

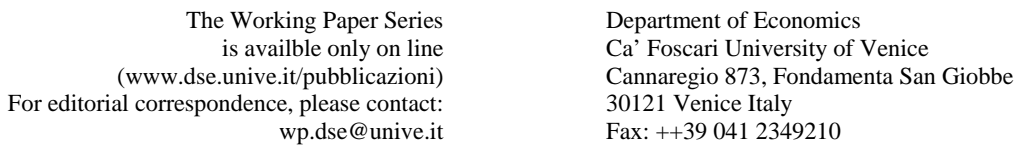




\section{Two alternative conceptions of money}

In the history of economic thought the relationship between money and market has been interpreted from two contrasting points of view. On the one hand, money is seen as an instrument created by individuals to overcome the difficulties involved in barter, its basic function being as a medium of exchange, while the other view has it that money developed before the market and that its principal function is that of a standard of value. Evidently, therefore, in the former case the unit of account function is seen to have emerged from a practice (exchange of goods and services) based on the advantages to be had for individuals seeking to maximise their utility, while in the latter case money emerges as a rule adopted by members of the community (the political authorities promoting it and ensuring it be respected) which pre-dates the market.

These contrasting views date back as early as the times of Aristotle, who defined money, alternatively, as a commodity selected by agents to serve as a medium of exchange, and as a simple token created by the political authorities to be used as a means of payment. In his Politics (I, 1257a) he argues that money is the means created by agents for convenience in exchanges, and that the State intervenes only subsequently to facilitate measurement of the weight and assessment of the quality of the chosen commodity (Aristotle 1977: 38-42). In the Nicomachean Ethics (V, 5, $1133 b)$, on the other hand, money is seen as a legal convention - a measure of value that enables the exchange of goods and thus collaboration between members of the polis. Money is a social convention, and performs its function by dint of a decision made by the political authorities (Aristotle 1982: 284-8).

Aristotle's two theories represent a heritage that has been drawn upon throughout the history of pre-modern economic thought, and it was not until the eighteenth century that a significant change came about. It was then, with the dawn of political economy, that its theoreticians (Hume, Quesnay, Smith...) levelled their critical fire at mercantilism as a convenient target to match themselves against. The thesis to be confuted was that true wealth lay in gold and silver: for the sake of the country's prosperity, therefore, it was necessary to accumulate the precious metals. Actually, this 
was not the mercantilist idea; rather, it held that the accumulation of the precious metals by virtue of a positive balance of trade was but a consequence of the economic system's capacity to produce wealth and generate employment. This idea was to be rediscovered and subjected to searching analysis by Keynes after a lapse of 150 years, as we shall see later on.

The idea that it was money that represented true wealth was not hard to confute. For the classical economists it sufficed to observe that wealth was a composite set of useful things, while money was but a means to facilitate exchange. What counted was not the wealth and power of the State but the wellbeing of the individual members of the community. The criticism advanced by the classical economists had great success, in the space of fifty years sweeping away the mercantilist doctrine, which remained confined to government practices ignored by the new theory. So it was classical political economy described the functioning of the market economies, drastically downsizing the role and importance of money.

One possible reason for this outcome is that money, like the State or income distribution, represented a formidable stumbling block for an economic science to be constructed on the model of Newtonian physics, eliciting those natural laws that govern the economic world. If only it were demonstrated that economic activity was subject to natural laws - not human, that is, and so immutable - all that governments could do would be to respect them and seek to remove the obstacles compromising their efficacy. This interpretation of the economic world offered support to the social groups emerging in the society of the ancien régime: entrepreneurs, bankers, shipowners, insurers, property-owners and capitalists and, in general, all who looked to the development of production and trade to promote and consolidate their own positions in society. Asserting the existence of natural laws to which the production (and distribution) of wealth was subject meant denying the legitimacy of interventionist government policies, while at the same time calling for extension of the autonomy and freedom of initiative of the private agents operating in the economic field. It also required that the tools employed by the political authorities to regulate the market economy and keep it under control, such as taxes, income distribution and money, be blunted and relegated to a marginal role. 
And the classical economists accordingly concentrated their attention on the private sector, confining within narrow limits the scope for action by the State, limited to providing the essential services for the functioning of the economic system, or, in short, defending property. Money was to be seen as a mere medium of exchange: a "neutral" means that was not to interfere in the determination of prices but simply to ensure transparency for the "signals" they transmit to the production and consumption decision-makers. Like the wheel or the steam engine, money was but a technical means to reduce production costs: in the specific case, to guarantee that productive specialisation and the market prove advantageous. There is no need to invoke the social aspect of economic activity to account for its existence: it is enough to consider the exchange of goods and services between individuals pursuing self-interest, society being simply the sum of individuals collaborating among themselves through exchange.

\section{Money in history}

Historical evidence in support of the idea that money existed before the market is offered by the wergeld and the tally, two institutions that have come under the lens of anthropologists and historians of economics and law. 'Wergeld' is a term from old German referring to compensation for the murder of a member of the community or some offence against his person, family or patrimony. It is a practice we find documented in pre-classical Greece, and among the Celtic, Germanic, Scandinavian and Slav populations of the Dark Ages. Apparently the aim was to assuage the wrath of the injured party or his family and prevent the outbreak of feuds, seen as threatening the solidity of social structures. Both the offences and compensations were assessed through common practice, which ensured the force of a binding principle.

It has been observed that the English verb 'to pay'(from the French payer), referring to settlement of a debt, derives from the Latin pacare, which means 'to pacify' and refers to the process of seeking an agreement with the injured party to prevent his revenge. According to Grierson (1977: 22), geld (a term cognate with the Old English gild, geld) indicates a unilateral payment (a fine, a tax, compensation or a feudal due), while werd recalls the English 'worth', from the root word wair ('man'), like the Latin vir. 
Weorp or wairp are Old English terms indicating 'price', although, Grierson suggests (ibid.), the second of the two terms 'may have included a more sinister element', in that it referred specifically to the price of a slave. Thus the connection with the evaluation of goods, at first sight totally lacking, could be detected in the institution of slavery, much like that of the bride's wealth. Both are attested with certainty in ancient Greece, as indeed in the barbarian societies of western Europe, and may have represented the medium by means of which the assessment of offences could be extended from person to patrimony, and thus to all goods of economic value. Grierson (ibid.) goes on to point out that in Greek poléin ('to sell') originally referred to the sale of a person as slave, while the term timé ('price') included in its connotation the sense of 'compensation', 'satisfaction' and derived from the same root as timoréin ('to have revenge’).

A further point made in this respect (Wray 1998: 49) is that, supposing that it was in fact wergeld that lay behind the notion of debt and the search for a measure of value, the decisive factor determining its introduction was probably the need to establish the amount of levies. It is surely significant that in Mesopotamia, where the State first entered the scene, the standard of value was based on the unit of weight of the most common cereals, wheat and barley. This standard of value, or unit of account, is money in its primitive state, compatible, and - as the historical documentation shows, actually associated - with a wide range of objects serving as means of payment. A significant example is offered by the tally.

According to certain scholars (Innes 1913: 394 and 396; Davies 1994: 147-52), for many centuries the major means of payment in Europe was the tally, a stick of squared hazel-wood with notches cut into it to indicate how much the debt came to. The name of the debtor and date of the contract were written on either side of the stick, which was then cut in two lengthwise, thus splitting the notches into two parts, each with the name of the debtor and date of the contract. The cut in the stick stopped about an inch short of the end; the longer part, called the stock, was held by the creditor, while the shorter, called the stub, was left to the debtor. On payment the two parts of the stick were brought back together to verify the effective sum of the debt. In England the tally became increasingly important as from the twelfth century, to peak in the period preceding the foundation of the Bank of England. This momentous event did not put an 
end to use of the tally, which continued for over a century up to its termination in 1834 . The factors behind the spread of the tally were the ban on usury and the scarcity of currency. In the course of time the tally became a wooden bill by means of which it was possible not only to obtain credit harmless of the penalties laid down by the law, but also to settle any debts and acquire commodities of all sorts (Innes 1913: 396). It was rapidly adopted by the Treasury. The first step consisted in the assignment with which the Exchequer transferred the taxpayers' debt to the sovereign's creditors, handing over the stock. Next came the tallia dividenda, which were consigned to the court suppliers, and refunded on expiration by the Exchequer like modern-day state bonds. Finally, at a later stage the tallies were issued in great quantities by the Treasury as advances on fiscal revenue, and holders could trade them for money on the market. Thus, as Davies points out (1994: 150), 'a system of discounting tallies arose especially in London, operated in a number of recorded instances by officials working in the Exchequer'.

A function much like that of the tally was, according to Innes (1913: 395-6), served in Babylonia by clay tablets called shubati ('receipt') on which were recorded the quantity of goods sold - wheat, for example - the name of the issuer and that of the recipient, together with his seal and the name shubati. There were two ways to prevent counterfeiting: either the tablets could be deposited in a temple, or they could be sealed in a closed container that had to be broken like a money box to get at the tablets. In the latter case all the details recorded on the tablets were copied onto the container, except for the recipient's name and seal. The container was broken only when payment was carried out, and the inscriptions could thus be compared. Unlike the tablets deposited in the temples, those sealed in containers could circulate like the tallies.

What the tallies and shubati tablets have in common is that they both certificated debts and served as means of payment, disappearing from circulation once the credit was offset by a debt of the same amount, as was the practice with letters of exchange in the medieval fairs. Some scholars argue that these records could not be considered money since the settlement of any remaining debt was, once compensation had been performed, probably concluded with money proper, or in other words minted gold and silver. Others point out that the shubati tablets were documented in Babylonia at least 2500 years before the kings of Lydia minted the fist metal coins around the second half 
of the seventh century BC. On the other hand, the metal currency that we are accustomed to consider real money seems to have come into existence as certification of the sovereign's debt to the subjects whose goods and services he acquired mercenary soldiers, for example, or suppliers liable to pay taxes (Grierson 1977: 10). It was no great problem for the political authorities to have their promises of payment accepted in exchange for goods and services since they were able to levy taxes and stated their readiness to accept their own promissory notes in payment. The use of costly supports such as gold and silver, which were rare metals and, in the absence of mines, usually came with war booties, is generally explained as a way of avoiding forgeries.

Supposing that the function of a means of payment was served from the very outset not by a commodity but by a certificate of debt issued by an agent enjoying the confidence of the public, then the introduction of money seems obviously not due so much to the agents' intention to reduce the costs of exchanges as to the fact that the issuer claims credit of the community and so is able to levy taxes. Thus money takes the form of an institution transcending the purely economic sphere in that it guarantees the exchange of goods and services between governors and governed, and with it the very foundations of social order. Like every other institution, this, too, owes its existence to the decision of the groups holding power to establish it, and the ability of those representing these groups to exact the respect of the entire community.

\section{Two alternative views of market}

As in the case of money, also for the market two approaches have come into confrontation in the course of the history of economic thought. With the first the market is seen as a column bearing the economies characterised by private property and freedom of enterprise. It represents the means by which members of society democratically come to decisions about the use of resources and distribution of income. Thanks to the market, in fact, all individuals, whatever their role, wealth or education, engage in the decision-making process on an equal footing with all the others. In the second approach, on the other hand, the market is seen as the means by which decisions on the use of resources and distribution of income, once taken by the 
groups enjoying economic command, are passed on to the other members of society to be implemented. In the first case the market lies at the heart of the system and serves to prevent the enjoyment of privileges and position rents by some members of society excluding others, while in the second it merely plays a supporting role for the existing patterns of power.

What does, however, distinguish a market economy? In centrally managed economic systems like the "hydraulic" economies of Mesopotamia and ancient Egypt (Wittfogel 1959), the European feudal system or the planned economy of the former Soviet Union, those in charge of the economy exercise their decision-making powers regarding the channelling of resources and distribution of income giving direct orders to those working under them. In the market economy, by contrast, in order to exercise their power the figures in charge of the economy make use of indirect orders, which take the form of contracts: thus it is not immediately evident that real orders are being given. While we cannot but recognise the fact that any exchange presupposes the existence of needs that cannot be satisfied autonomously by those involved, we must also bear in mind that not all parties share the same degree of urgency; thus dependence on the counterparty is greater for some than for others. The most significant exchanges that take place in a market economy, like the buying and selling of work services, consumption goods or securities, are characterised by a distinct difference in the power of the two parties. Here the term 'power' is understood as a relationship between two social agents when there is conflict in their aims or values, or on the line to follow to achieve them. One of the two agents accedes to the other's demands for fear that he may deprive him of one or more values which he holds dearer than those he is to sacrifice. In other words, power always goes hand in hand with a sanction, and involves a degree of rationality since the agent exercising it looks to the counterparty's capacity to weigh up his own advantage.

It is in the exercise of power that we find the key to the functioning of market economies. As we are reminded by Marglin (1974: 51-3), at the time of the industrial revolution entrepreneurs were able to get the workers into their factories only by facing them with the choice of working or starving. Discharged soldiers, peasants driven from their villages with the enclosure of common land, orphaned minors placed in the charge of the parishes for periods of even ten or more years, wives and children of 
home-based workers sent to the factories by their respective husbands and fathers to eke out the family income, and 'the scum of every class and of every occupation' (Mantoux 1961: 375) - such was the human material that composed the first generation of factory workers. The process was repeated in the course of capitalistic development, to the point that wage labour became a 'natural' fact that had no need of explanation.

What we witness here is the quest for positions of power by economic agents on the strength of which they can bend the behaviour of other agents to their purposes. If we see it in these terms, we can appreciate the concern of the early critics of the market, who contested the vaunted capacity of the system to guarantee equality for the members of society, keeping the privileges and inequalities that had characterised the society of the ancien régime from setting in once again. The exponents of political economy answered back with the metaphor of the "invisible hand", an ideal mechanism situated outside time that was entrusted with the task of guaranteeing freedom of access to economic activity in all its forms, together with efficiency in the use of resources and fairness in the distribution of income. The mechanism was to be descried in the market price system and the free play of forces in competition; acceptance of this interpretative scheme has long been - and indeed remains - a dominant feature of economic reasoning.

\section{The power structure of the economy}

The alternative conception that sees in the market a social institution historically determined, like money, property or the State, derives from the idea that every economic system rests on a clearly defined power structure that assigns to certain individuals the authority to decide on the use of resources and the allocation of the final product. With its assumed price equilibrating mechanism, the market loses its central position to take on a more modest role as technical means to facilitate the exercise of power by those in control of the economy. Productive efficiency and distributive equity prove illusory, and with them evaporates the theoretical importance attached to the quest for positions of equilibrium. 
It is in fact the theory of effective demand formulated by Keynes (and Kalecki) that offers this alternative. The demand for goods and services expressed by the community contains active and passive components, or in other words some elements (active) that determine others (passive), but are not in turn determined by them: in the industrial economies the investments made by firms are the active component of global demand, while family consumption constitutes the passive part. In this new scheme the market is merely the means employed by firms (or the social groups that have some interest or other in their success) to achieve the end of unlimited accumulation of wealth. In a capitalistic system firms advance the liquid assets obtained from the banks, hire the workers, use their services to produce gods, and subsequently sell their consumption goods and stock in order to regain possession of the money they advanced, keeping for themselves part of the capital goods after paying the banks their interest.

As had already been pointed out by Marx, in a system of this type the economic process can be summed up with the sequence: $D-M-D$, where $M$, which stands for the goods, and thus for the market, performs an instrumental role with respect to $D$, money, which constitutes the condition and objective of the entire process. Keynes takes explicit reference from this scheme when he introduces the distinction between 'cooperative economy' and 'entrepreneur economy' (1979: 81). The former is purely conjectural and constitutes the object of study in traditional theory, while the latter, which actually exists, is to be examined with a new approach which he terms ‘monetary theory of production' (1979: 49-50).

This is the picture of the market that emerged in sharp definition subsequent to contributions by Keynes, Kalecki and economists following in their wake, but its origins are quite remote, going back at least to Cantillon, who described the preindustrial economy of the ancien régime as consisting of two classes: the landowners (the independent class) on one side, and the entrepreneurs and wage workers (the dependent class), on the other. The property owners' spending on luxury goods constitutes the active component of the global demand, upon which depends the necessary consumption of the dependent class. Since the entrepreneurs produce only what they believe they can sell at a remunerative price, the market assumes the form of a means used by the property owners to transmit to the producers the decisions to be 
taken on the utilization of resources. Distribution of the final product between rents and wages is also decided by the market on the basis of the power relations between property owners and the dependent class. Obviously, this is a sui generis market picture in which the property owners' wishes are law, since - as he points out - if they 'close their Estates and will not suffer them to be cultivated, it is clear that there would be neither Food nor Rayment for any of the Inhabitants' (Cantillon 1964: 43; see also Giacomin 1994).

Thus Cantillon, like Keynes and Kalecki, held that the position of a social group in command over others rests on the possibility it has to abstain from spending its income for a period of time long enough to condition the existence of the others. However, we must also bear in mind that a significant change occurred in transition from preindustrial to advanced industrial economy. The land owners departed from the scene, and the banks set up in their place. It is the banks that control access to resources for the producers. The rents taken by the landowners of the ancien régime are now represented by the interest obtained by the banks on the financing of enterprises. The task has passed to them to determine with their investments the directions resources are to take and the intensity of their use. The amount of the investments determines the demand for labour and, subsequently, the supply of goods and services. All that remains for the workers to do is to adjust their spending on consumption goods and stock to the income available in observance of their budget constraint. The markets that see bargaining engaged in for the granting of credit, the hiring of manpower and the sale of consumption goods and stock show on the supply side a non-competitive structure ranging from oligopoly, concentrated or differentiated, through more or less disguised forms of collusion to out-and-out monopoly.

According to the metaphor of the invisible hand attributed to Adam Smith ${ }^{1}$ and embraced in the scheme of general economic equilibrium, through the market individuals guided purely by self-interest are driven unwittingly and willy-nilly to achieve ends of general interest such as equal access to roles, efficient use of resources and fair distribution of product.

According to the alternative view, on the other hand, the market is a social institution that reflects the particular needs of each system and is to be understood in the light of a pattern of power that assigns economic dominance to one or more groups of agents 
with the exclusion of others. The pattern emerges transparently from the hierarchy formed among the components of global demand. The fact that the enterprise investments play an active role in a capitalistic system while family consumption is left with a passive role is neither a matter of chance nor arbitrary. Rather, it is the natural consequence on the economic plane of a supremacy sanctioned at the institutional level through the right to property, freedom of economic enterprise and the state's abstention from direct management of productive activities. With the support of the banks, it is the enterprises that control access to resources, including labour, since there is a vast supply of people compelled to sell their personal services to earn a living, and compelled to accept the conditions laid down by the enterprises with regard to income distribution. In other words, wages have to be set at a level that leaves room for the enterprises to make profits, whatever the workers' needs may be.

On the other hand, the conception of the market as a mechanism bending the action of individuals to the pursuit of aims of general interest leaves economic facts devoid of explanatory power, renders superfluous the analysis of effective demand as an element linking institutions and productive machinery, and relegates money to a subordinate, inessential role.

\section{Notes}

1 The attribution of this theory to Smith has been hotly contested by authoritative scholars (cf., e.g. Rothschild 1994 and Roncaglia 2005), who see in it an attempt lacking any textual support to enlist the father of economic science among the upholders of a view that emerged only subsequently, in the sphere of marginalist thought.

\section{References}

Aristotle (1977) Politics, Cambridge, MA: Harvard University Press

(Loeb Classical Library). 
(1982) Nicomachean Ethics, Cambridge, MA: Harvard

University Press (Loeb Classical Library).

Cantillon, R. (1964) Essay on the Nature of Trade in General, ed. by H. Higgs,

New York: Augustus M. Kelley.

Davies, G. (1994) A History of Money: From Ancient Times to the Present Day, Cardiff: University of Wales Press.

Giacomin, A. (1994) 'Richard Cantillon: Potere, Domanda Effettiva e

Popolazione in una Economia Pre-industriale’, Studi Economici, 52: 5-41.

Grierson, P. (1977) The Origins of Money, London: The Athlone Press.

Innes, A. M. (1913) 'What is Money’, Banking Law Journal, 25: 377-408.

Keynes, J. M. (1979) The Collected Writings of John Maynard Keynes, vol.

XXIX: The General Theory and After. A Supplement, ed. by D. E.

Moggridge, London: Macmillan and Cambridge University Press for the

Royal Economic Society.

Mantoux, P. (1961) The Industrial Revolution in the eighteenth century,

London: J. Cape.

Marglin, S. (1974) 'What Do Bosses Do? The Origins and Functions of

Hierarchy in Capitalist Production', The Review of Radical

Political Economy, 6: 33-60.

Rotschild, E. (1994) 'Adam Smith and the Invisible Hand', American

Economic Review, Papers and Proceedings, 84: 319-22.

Roncaglia, A. (2005) Il Mito della Mano Invisibile, Roma and Bari: Giuseppe Laterza \& Figli spa.

Wittfogel, K. A. (1959) Oriental Despotism. A Comparative Study of Total 
Power, New Heaven: Yale University Press.

Wray, L. R. (1998) Understanding Modern Money. The Key to Full

Employment and Price Stability, Cheltenham, UK and Northampton, SA:

Edward Elgar. 